\title{
Predictors of hypoxaemia in hospital admissions with acute lower respiratory tract infection in a developing country
}

\author{
Martin W Weber, Stanley Usen, Ayo Palmer, Shabbar Jaffar, E Kim Mulholland
}

\begin{abstract}
Since oxygen has to be given to most children in developing countries on the basis of clinical signs without performing blood gas analyses, possible clinical predictors of hypoxaemia were studied. Sixty nine children between the ages of 2 months and 5 years admitted to hospital with acute lower respiratory tract infection and an oxygen saturation $\left(\mathrm{SaO}_{2}\right)<90 \%$ were compared with 67 children matched for age and diagnosis from the same referral hospital with an $\mathrm{SaO}_{2}$ of $90 \%$ or above (control group 1), and 44 unreferred children admitted to a secondary care hospital with acute lower respiratory infection (control group 2). Using multiple logistic regression analysis, sleepiness, arousal, quality of cry, cyanosis, head nodding, decreased air entry, nasal flaring, and upper arm circumference were found to be independent predictors of hypoxaemia on comparison of the cases with control group 1. Using a simple model of cyanosis or head nodding or not crying, the sensitivity to predict hypoxaemia was $59 \%$, and the specificity $94 \%$ and $93 \%$ compared to control groups 1 and 2 , respectively; $80 \%$ of the children with an $\mathrm{SaO}_{2}<80 \%$ were identified by the combination of these signs. Over half of the children with hypoxaemia could be identified with a combination of three signs: extreme respiratory distress, cyanosis, and severely compromised general status. Further prospective validation of this model with other datasets is warranted. No other signs improved the sensitivity without compromising specificity. If a higher sensitivity is required, pulse oximetry has to be used.

(Arch Dis Child 1997;76:310-314)
\end{abstract}

Keywords: hypoxaemia; clinical signs; pneumonia; developing countries

Hypoxaemia is the most serious manifestation of severe pneumonia in children. The case fatality rate of pneumonia is inversely related to the arterial haemoglobin oxygen saturation $\left(\mathrm{SaO}_{2}\right) .{ }^{1}$ As respiratory infections are one of the main causes of death in children in developing countries, ${ }^{2}$ and the delivery of oxygen to hypoxaemic children may improve the outcome, the detection of hypoxaemia is important. The most reliable way to do this is an arterial blood gas analysis or the determination of the arterial haemoglobin $\mathrm{SaO}_{2}$ by pulse oximeter. However, machines to make these measurements are expensive, need constant maintenance, and are not widely available in developing countries. To help health professionals decide which children are hypoxaemic and might benefit from oxygen treatment, we have studied the signs and symptoms indicating hypoxaemia in children with pneumonia.

\section{Methods}

PATIENTS

The study was performed in the paediatric ward of the Royal Victoria Hospital (RVH) in Banjul, the only tertiary paediatric referral hospital in the Gambia, and in the hospital of the Medical Research Council (MRC) in Fajara, a primary and secondary care institution serving a predominantly periurban population. Children between 2 months and 5 years of age were included if they presented with an acute lower respiratory tract infection and had no signs of congenital heart disease or meningitis. The case children had an arterial haemoglobin $\mathrm{SaO}_{2}$ of $<90 \%$, measured by pulse oximeter. This $\mathrm{SaO}_{2}$ is generally considered to reflect severe hypoxaemia. Control group 1 comprised children who were referred to the ward of the RVH with the same diagnosis and exclusion criteria as the cases but who had an $\mathrm{SaO}_{2}$ of $90 \%$ or above. These children were matched to the case children for age and for the clinical diagnosis of bronchiolitis or pneumonia. As they were matched controls, their status of having an $\mathrm{SaO}_{2}$ of $90 \%$ or above was known to the investigator. Therefore, a second control group was enrolled: control group 2 comprised of unreferred patients with acute lower respiratory tract infection who presented to the outpatient department of the MRC laboratories. These children were examined without knowledge of the $\mathrm{SaO}_{2}$. The children in control group 2 were enrolled as part of an evaluation of the World Health Organisation (WHO)/Unicef sick child algorithm and comprised children in this group with a diagnosis of acute lower respiratory tract infection. According to the severity of the condition, children were admitted or treated as outpatients. Children with $\mathrm{a} \mathrm{SaO}_{2}$ below $90 \%$ and children who were not admitted were excluded from the analysis.

A history was obtained from the caretaker. First, the complaints and duration of complaints were asked for in an open manner. Then 
Table 1 Patient characteristics

\begin{tabular}{|c|c|c|c|c|}
\hline & & Cases & $\begin{array}{l}\text { Control group } 1 \\
R V H\end{array}$ & $\begin{array}{l}\text { Control group } 2 \\
M R C\end{array}$ \\
\hline No & & 69 & 67 & 44 \\
\hline Age (months) & $\begin{array}{l}\text { Median } \\
(25 \%, 75 \%)\end{array}$ & $\begin{array}{l}12 \\
(6,19)\end{array}$ & $\begin{array}{l}12 \\
(6,18)\end{array}$ & $\begin{array}{l}17 \\
(7,23)\end{array}$ \\
\hline Sex & $\begin{array}{l}\text { Female/male } \\
\text { (\% female) }\end{array}$ & $\begin{array}{l}33 / 36 \\
(48 \%)\end{array}$ & $\begin{array}{l}37 / 30 \\
(55 \%)\end{array}$ & $\begin{array}{l}18 / 26 \\
(41 \%)\end{array}$ \\
\hline $\mathrm{SaO}_{2}$ & $\begin{array}{l}\text { Median } \\
(25 \%, 75 \%)\end{array}$ & $\begin{array}{l}82 \\
(72,85)\end{array}$ & $\begin{array}{l}96 \\
(94,98)\end{array}$ & $\begin{array}{l}96 \\
(95,98)\end{array}$ \\
\hline
\end{tabular}

specific questions about the history of the child were asked. The physical examination documented the general status of the child, specific respiratory findings, vital signs, and anthropometric measurements. The categories of the signs are shown together with the results in the tables. Head nodding is a movement of the head synchronous with each breath, which is caused by increased use of auxiliary muscles of respiration and therefore indicates severe respiratory distress. All observation were done by a single observer (MWW). Weight for age was calculated using the United States National Center for Health Statistics (NCHS) standard as comparison. If possible, a chest radiograph was obtained, which was read in a blinded manner by one of us (EKM). Parenchymal changes were classified in the following way: (a) none; (b) minor-consistent with pneumonia in the presence of supportive physical findings; (c) major-diagnostic of pneumonia by itself, but no lobar consolidation; (d) lobar consolidation. The presence of pleural changes, pneumothorax, and hyperinflation was also noted.

Verbal consent was obtained from the caretaker and all explanations were given by a field assistant who spoke the appropriate language. The study was approved by the Gambian Government/MRC ethics committee.

STATISTICAL ANALYSIS

Comparisons between continuous normally distributed data were made using the $t$ test after application of Bartlett's test for homogeneity of

Table 2 Chest radiograph findings. Percentages in brackets

\begin{tabular}{|c|c|c|c|c|c|c|}
\hline Sign & Categories & $\begin{array}{l}\text { Oxygen } \\
\text { cases }\end{array}$ & $\begin{array}{l}\text { Control } \\
\text { group } 1 \\
\text { RVH }\end{array}$ & $\begin{array}{l}\text { Control } \\
\text { group } 2 \\
\text { MRC }\end{array}$ & $\begin{array}{l}p \text { Value } \\
\text { cases } v \\
\text { control } \\
\text { group } 1\end{array}$ & $\begin{array}{l}p \text { Value } \\
\text { cases v } \\
\text { control } \\
\text { group } 2\end{array}$ \\
\hline $\begin{array}{c}\text { No of } x \text { rays } \\
\text { obtained }\end{array}$ & & $60(87 \%)$ & $58(87 \%)$ & $36(82 \%)$ & & \\
\hline Quality & $\begin{array}{l}\text { Fair } \\
\text { Poor } \\
\text { Unreadable }\end{array}$ & $\begin{array}{l}56(93) \\
2(3) \\
2(3)\end{array}$ & $\begin{array}{l}52(90) \\
5(9) \\
1(2)\end{array}$ & $\begin{array}{l}35(97) \\
1(3)\end{array}$ & & \\
\hline Consolidation & $\begin{array}{l}\text { None } \\
\text { Minor } \\
\text { Major } \\
\text { Lobar }\end{array}$ & $\begin{array}{l}6(10) \\
13(22) \\
29(50) \\
10(17)\end{array}$ & $\begin{array}{l}9(16) \\
20(35) \\
14(25) \\
14(25)\end{array}$ & $\begin{array}{l}4(11) \\
7(19) \\
13(36) \\
12(33)\end{array}$ & 0.06 & 0.3 \\
\hline $\begin{array}{l}\text { Pleural } \\
\text { involvement }\end{array}$ & $\begin{array}{l}\text { None } \\
\text { Effusion } \\
\text { Pyopneumo- } \\
\quad \text { thorax }\end{array}$ & $\begin{array}{l}51(88) \\
5(9) \\
2(3)\end{array}$ & $\begin{array}{l}52(91) \\
5(9)\end{array}$ & $\begin{array}{l}35(97) \\
1(3)\end{array}$ & 0.8 & 0.25 \\
\hline Hyperinflation & Present & $17(29)$ & $21(37)$ & $3(8)$ & 0.5 & 0.04 \\
\hline
\end{tabular}

variance, while non-normally distributed data were compared using the Wilcoxon test. Discrete data were compared using the $\chi^{2}$ with Yate's correction or Fisher's exact test if the frequencies were small.

The predictors of hypoxaemia were determined using multiple logistic regression models. Models were compared between one another using changes in deviance with the corresponding changes in degrees of freedom which follow a $\chi^{2}$ distribution (likelihood ratio test). Analyses were performed using SPSS for Windows, SAS for Windows, and Epi-Info software packages.

\section{Results}

Sixty nine children with an acute lower respiratory tract infection and hypoxaemia, together with 67 controls with an $\mathrm{SaO}_{2}$ of $90 \%$ or above, were seen at RVH. Eighty three unreferred children with a diagnosis of acute lower respiratory tract infection were seen at the MRC hospital. Of those seen at the MRC hospital, three had an $\mathrm{SaO}_{2}$ below $90 \%$ and were excluded from the study, 36 were treated as outpatients and, as the disease was much milder in these cases, not considered in this analysis, and 44 were admitted to the ward. A clinical diagnosis of bronchiolitis was made in nine of the cases $(13 \%)$, in eight $(12 \%)$ of the children in control group 1 , and in four $(9 \%)$ of the children in control group 2. Six of the cases, but none of the controls, had measles as concurrent diagnosis. The characteristics of the patients in the three groups are listed in table 1 , the findings on examination of the chest radiographs in table 2.

The median $(25 \%, 75 \%$ quartiles) duration of illness was four days $(3,7)$ for the cases, three days $(3,4)$ for control group 1 , and three days $(3,5)$ for control group 2 ( $p=0.1$ for cases $v$ control group $1, \mathrm{p}=0.5$ for cases $v$ control group 2).

\section{VOLUNTEERED COMPLAINTS}

Rashes were significantly more common in the cases than in control group $1(10 \% v 0 \%, \mathrm{p}=$ 0.01 ), cough more common in cases than in control group $2(71 \% v 50 \%, p=0.04)$, and abdominal pain more common in control group 2 than in the cases $(16 \% v 0 \%, \mathrm{p}=$ $0.001)$. Otherwise, there was no significant difference between the groups in volunteered complaints.

SYMPTOMS ON DIRECT QUESTIONING

Moderate or severely reduced feeding was present in $29(42 \%)$ of the cases, in $15(22 \%)$ of children in control group 1 , and in five $(11 \%)$ of children in control group $2(p=0.02$ for cases $v$ control group $1, \mathrm{p}=0.001$ for cases $v$ control group 2).

Convulsions were reported in $10(15 \%)$ of the cases, in two $(3 \%)$ of children in control group 1, and in seven (16\%) of children in control group 2 ( $\mathrm{p}=0.04$ for cases $v$ control group $1, \mathrm{p}=1$ for cases $v$ control group 2); abnormal sleepiness in 29 (42\%) of cases, in 15 $(22 \%)$ of children in control group 1 , and in seven $(16 \%)$ of children in control group $2(\mathrm{p}=$ 
Table 3 Physical signs reflecting the general status of the child. Percentages in brackets

\begin{tabular}{|c|c|c|c|c|c|c|}
\hline Sign & Categories & $\begin{array}{l}\text { Oxygen } \\
\text { cases }\end{array}$ & $\begin{array}{l}\text { Control } \\
\text { group } 1 \\
\text { RVH }\end{array}$ & $\begin{array}{l}\text { Control } \\
\text { group } 2 \\
\text { MRC }\end{array}$ & $\begin{array}{l}p \text { Value } \\
\text { cases } v \\
\text { control } \\
\text { group } 1\end{array}$ & $\begin{array}{l}p \text { Value } \\
\text { cases } v \\
\text { control } \\
\text { group } 2\end{array}$ \\
\hline Appearance & $\begin{array}{l}\text { Normal } \\
\text { Sick } \\
\text { Very sick }\end{array}$ & $\begin{array}{l}4(6) \\
34(49) \\
31(45)\end{array}$ & $\begin{array}{l}4(6) \\
54(81) \\
9(13)\end{array}$ & $\begin{array}{l}10(23) \\
26(59) \\
8(18)\end{array}$ & $<0.0001$ & 0.002 \\
\hline Arousal & $\begin{array}{l}\text { Normal } \\
\text { Lethargic } \\
\text { Unresponsive }\end{array}$ & $\begin{array}{l}21(30) \\
43(62) \\
5(7)\end{array}$ & $\begin{array}{l}52(78) \\
15(22) \\
0(0)\end{array}$ & Not done & $<0.0001$ & - \\
\hline Attentiveness & $\begin{array}{l}\text { Engages } \\
\text { Decreased } \\
\text { Dull }\end{array}$ & $\begin{array}{l}19(28) \\
44(64) \\
6(9)\end{array}$ & $\begin{array}{l}48(72) \\
19(28) \\
0(0)\end{array}$ & $\begin{array}{l}29(66) \\
15(34) \\
0(0)\end{array}$ & $<0.0001$ & $<0.0001$ \\
\hline Movement & $\begin{array}{l}\text { Spontaneous } \\
\text { Stimulation } \\
\text { Pain } \\
\text { None }\end{array}$ & $\begin{array}{l}44(64) \\
20(29) \\
2(3) \\
3(4)\end{array}$ & $\begin{array}{l}63(94) \\
4(6) \\
0(0) \\
0(0)\end{array}$ & $\begin{array}{l}41(93) \\
3(7) \\
0(0) \\
0(0)\end{array}$ & $<0.0001$ & 0.005 \\
\hline Ability to feed & $\begin{array}{l}\text { Normal } \\
\text { Decreased } \\
\text { Not able } \\
\text { Not interested }\end{array}$ & $\begin{array}{l}20(29) \\
38(55) \\
11(16) \\
0(0)\end{array}$ & $\begin{array}{l}45(67) \\
20(30) \\
1(1) \\
1(1)\end{array}$ & $\begin{array}{l}27(61) \\
16(36) \\
1(2) \\
0(0)\end{array}$ & $<0.0001$ & 0.001 \\
\hline Quality of cry & $\begin{array}{l}\text { Vigorous } \\
\text { Weak } \\
\text { Hot }\end{array}$ & $\begin{array}{l}20(29) \\
36(52) \\
13(19)\end{array}$ & $\begin{array}{l}45(67) \\
21(31) \\
1(1)\end{array}$ & $\begin{array}{l}29(66) \\
14(32) \\
1(2)\end{array}$ & $<0.0001$ & $<0.0001$ \\
\hline Consolability & $\begin{array}{l}\text { Quiets down } \\
\text { Irritable } \\
\text { Continues crying } \\
\text { Does not cry }\end{array}$ & $\begin{array}{l}37(54) \\
16(23) \\
1(1) \\
15(22)\end{array}$ & $\begin{array}{l}47(70) \\
13(19) \\
6(9) \\
1(1)\end{array}$ & $\begin{array}{l}25(57) \\
17(39) \\
2(5) \\
0(0)\end{array}$ & 0.001 & 0.005 \\
\hline Tone & $\begin{array}{l}\text { Normal } \\
\text { Hypertonic } \\
\text { Hypotonic }\end{array}$ & $\begin{array}{l}57(83) \\
1(1) \\
11(16)\end{array}$ & $\begin{array}{l}65(97) \\
0(0) \\
2(3)\end{array}$ & $\begin{array}{l}43(98) \\
0(0) \\
1(2)\end{array}$ & 0.02 & 0.048 \\
\hline
\end{tabular}

0.02 for cases $v$ control group $1, \mathrm{p}=0.007$ for cases $v$ control group 2). Irritability was inversely related to hypoxaemia; it was reported in $28(41 \%)$ of cases, in $38(57 \%)$ of children in control group 1 , and in $28(64 \%)$ of children in control group 2 ( $\mathrm{p}=0.09$ for cases $v$ control group $1, \mathrm{p}=0.03$ for cases $v$ control group 2 ).

Cough, difficulty in breathing, fast breathing, noisy breathing, and diarrhoea were reported with similar frequency in cases and controls.

EXAMINATION FINDINGS

General observations on the status of the children are presented in table 3 . The findings on examination of the respiratory system are shown in table 4.

The nutritional status of the cases was significantly worse than in the controls. The weight for age ( $Z$ score, mean (SD)) was -2.17 (1.3) for the cases, -1.26 (1.6) for control group 1, and -1.08 (1.4) for control group 2 (p $=0.0003$ for cases $v$ control group $1, \mathrm{p}=0.001$ for cases $v$ control group 2). Children with measles were not significantly more malnourished than other children in the case group. Forty two of the cases $(61 \%)$ had a weight for age of below $80 \%$ of the NCHS standard, but only $22(33 \%)$ of the children in control group 1 and $16(36 \%)$ of the children in control group 2. The mean (SD) upper arm circumference was $12.0(1.7) \mathrm{cm}$ for cases, $13.0(1.5) \mathrm{cm}$ for control group 1, and 13.6 (1.3) cm for control group 2 ( $\mathrm{p}=0.0001$ for both comparisons).

The mean (SD) temperature was $38.3(1.2)^{\circ} \mathrm{C}$ for the cases, $38.7(1.1)^{\circ} \mathrm{C}$ for control group 1 , and $38.8(1.0)^{\circ} \mathrm{C}$ for control group $2(\mathrm{p}=0.07$ for cases $v$ control group 1 , $\mathrm{p}=0.02$ for cases $v$ control group 2).

The heart rate was not significantly different between groups.

MULTIPLE LOGISTIC REGRESSION

Using multiple logistic regression independent predictors of hypoxaemia when comparing the cases with control group 1 were sleepiness, arousal, quality of cry, cyanosis, head nodding, decreased air entry, nasal flaring, and upper arm circumference. When cases were compared with control group 2, difficulty in breathing as a volunteered complaint, sleepiness as a complaint, cyanosis, crepitations, respiratory rate, head nodding, upper arm circumference, and liver size were independent predictors.

SENSITIVITY AND SPECIFICITY OF DIFFERENT SIMPLE MODELS

Using a small number of variables from both comparisons above, the following model gave the best sensitivity combined with a reasonable specificity: presence of cyanosis, or head nodding, or not crying at all during examination. This model predicted the presence of hypoxaemia with a sensitivity $59 \%$ and a specificity of $94 \%$, compared with control group 1, and a sensitivity of $59 \%$ and a specificity of $93 \%$, compared to control group 2 . Changing these criteria to weak or absent cry, or head nodding, or cyanosis increased the sensitivity to $84 \%$, but lowered the specificity to $62 \%$ and $63 \%$ for control groups 1 and 2, respectively. Replacing the 'ability to cry' in above model with 'not feeding at all', being hypotonic, or being unresponsive to stimuli gave sensitivities of $59 \%, 58 \%$, and $56 \%$, respectively, whereas the specificities remained above $90 \%$.

The WHO criteria for giving oxygen ${ }^{4}$ of cyanosis, inability to drink, severe chest indrawing, or a respiratory rate over 70 breaths per minute predicted hypoxaemia with a sensitivity of $62 \%$ and specificities of $76 \%$ and $82 \%$ for control groups 1 and 2, respectively. Leaving out the respiratory rate in the WHO model increased the specificity to $96 \%$ and $95 \%$, respectively, and lowered the sensitivity to $52 \%$. A respiratory rate of $>70$ or grunting or severe indrawing for children under 12 months and a respiratory rate of $>60$ for older children as a single predictor of hypoxaemia, as proposed in a study from Kenya, ${ }^{1}$ gave a sensitivity of $71 \%$ and specificities of $47 \%$ and $61 \%$ for control groups 1 and 2, respectively.

Thirty children had an $\mathrm{SaO}_{2}$ of $<80 \%$. For this subgroup of the most severe cases, the model of absence of crying or head nodding or cyanosis had a sensitivity of $80 \%$, the WHO model with respiratory rate had a sensitivity of $80 \%$, the WHO model without respiratory rate had a sensitivity of $77 \%$, and the model based on the two cut off points for respiratory rate proposed in the study from Kenya had a sensitivity of $80 \%$. 
Table 4 Observed respiratory signs of the children. Percentages in brackets

\begin{tabular}{|c|c|c|c|c|c|c|}
\hline $\operatorname{Sign}$ & Categories & $\begin{array}{l}\text { Oxygen } \\
\text { cases }\end{array}$ & $\begin{array}{l}\text { Control } \\
\text { group } 1 \\
\text { RVH }\end{array}$ & $\begin{array}{l}\text { Control } \\
\text { group } 2 \\
M R C\end{array}$ & $\begin{array}{l}\text { p Value } \\
\text { cases } v \\
\text { control } \\
\text { group } 1\end{array}$ & $\begin{array}{l}p \text { Value } \\
\text { cases } v \\
\text { control } \\
\text { group } 2\end{array}$ \\
\hline Cough & Heard & $63(91)$ & $49(73)$ & $33(75)$ & 0.01 & 0.04 \\
\hline Nasal flaring & Present & $49(71)$ & $31(46)$ & $18(41)$ & 0.006 & 0.003 \\
\hline Nasal discharge & Present & $25(36)$ & $21(31)$ & $19(43)$ & 0.5 & 0.6 \\
\hline Cyanosis & Present & 27 (39) & $0(0)$ & $0(0)$ & $<0.0001$ & $<0.0001$ \\
\hline $\begin{array}{l}\text { Hyperinflation } \\
\text { of thorax }\end{array}$ & Visible & $13(19)$ & $13(19)$ & $1(2)$ & 1.0 & 0.008 \\
\hline Respiratory rate & $\begin{array}{l}\text { Mean } \\
\text { SD }\end{array}$ & $\begin{array}{l}62.6 \\
14.0\end{array}$ & $\begin{array}{l}61.3 \\
12.1\end{array}$ & $\begin{array}{l}54.7 \\
13.2\end{array}$ & 0.6 & 0.003 \\
\hline $\begin{array}{l}\text { Supraclavicular } \\
\text { indrawing }\end{array}$ & $\begin{array}{l}\text { None } \\
\text { Mild } \\
\text { Moderate } \\
\text { Severe }\end{array}$ & $\begin{array}{l}17(25) \\
27(39) \\
21(30) \\
4(6)\end{array}$ & $\begin{array}{l}37(55) \\
22(33) \\
8(12) \\
0(0)\end{array}$ & $\begin{array}{l}34(77) \\
10(23) \\
0(0) \\
0(0)\end{array}$ & 0.001 & $<0.0001$ \\
\hline $\begin{array}{l}\text { Intercostal } \\
\text { indrawing }\end{array}$ & $\begin{array}{l}\text { None } \\
\text { Mild } \\
\text { Moderate } \\
\text { Severe }\end{array}$ & $\begin{array}{l}24(35) \\
18(26) \\
24(35) \\
3(4)\end{array}$ & $\begin{array}{l}46(69) \\
14(21) \\
7(10) \\
0(0)\end{array}$ & $\begin{array}{l}35(80) \\
3(7) \\
6(14) \\
0(0)\end{array}$ & $<0.0001$ & $<0.0001$ \\
\hline $\begin{array}{l}\text { Lower chest } \\
\text { wall } \\
\text { indrawing }\end{array}$ & $\begin{array}{l}\text { None } \\
\text { Mild } \\
\text { Moderate } \\
\text { Severe }\end{array}$ & $\begin{array}{l}18(26) \\
17(25) \\
29(42) \\
5(7)\end{array}$ & $\begin{array}{l}25(37) \\
22(33) \\
18(27) \\
2(3)\end{array}$ & $\begin{array}{l}27(61) \\
8(18) \\
8(18) \\
1(2)\end{array}$ & 0.1 & 0.002 \\
\hline Grunting & $\begin{array}{l}\text { None } \\
\text { Occasional } \\
\text { Every breath }\end{array}$ & $\begin{array}{l}36(52) \\
23(33) \\
10(15)\end{array}$ & $\begin{array}{l}41(61) \\
22(33) \\
4(6)\end{array}$ & $\begin{array}{l}25(57) \\
16(36) \\
3(7)\end{array}$ & 0.2 & 0.5 \\
\hline Head nodding & Present & $18(29)$ & $3(4)$ & $3(7)$ & $<0.0001$ & 0.006 \\
\hline Crepitations & Present & $64(93)$ & $59(88)$ & $27(61)$ & 0.3 & $<0.0001$ \\
\hline Wheeze & Present & $15(22)$ & $12(18)$ & $5(11)$ & 0.4 & 0.4 \\
\hline Rhonchi & Present & $7(10)$ & $10(15)$ & $9(20)$ & 0.7 & 0.1 \\
\hline $\begin{array}{l}\text { Decreased air } \\
\text { entry }\end{array}$ & Present & $12(17)$ & $2(3)$ & $2(5)$ & 0.03 & 0.2 \\
\hline
\end{tabular}

\section{Discussion}

We could show in our study that a simple model of cyanosis, or head nodding, or absence of crying on examination could predict hypoxaemia $\left(\mathrm{SaO}_{2}<90 \%\right)$ with a sensitivity of $59 \%$ and a high specificity. A number of physical signs were highly significantly associated with hypoxaemia, but the sensitivity of each sign alone was low. Cyanosis has long been known to be associated with hypoxaemia, ${ }^{67}$ but the difficulty of its detection, especially in children with dark pigmentation of the skin, makes it an insensitive marker. In our study, the respiratory rate was a poor predictor of hypoxaemia, as found in other studies. ${ }^{8}{ }^{9}$ Irritability as a sign for hypoxaemia is based on observations in England, where a small number of children, mainly with bronchiolitis, became irritable when they were disconnected from oxygen. ${ }^{10}$ Other observers did not find this a helpful sign. ${ }^{7}$ In our series, irritability was inversely related to the presence of hypoxaemia, that is, hypoxaemic children tended to be more lethargic than irritable. The higher proportion of children with bacterial pneumonia might account for this finding. The influence of malnutrition on the severity of acute respiratory tract infection has been described before, ${ }^{1112}$ but it had not been shown, to our knowledge, that it is associated with hypoxaemia. As control group 1 was matched to the cases by age, we could not evaluate the effect of age. Unpublished observations in the RVH indicate that younger children are at higher risk for hypoxaemia, and the children in control group 2 tended to be older, though the difference in age was not statistically significant. The influence of age will have to be evaluated in future studies. Our study was performed at sea level. It has been shown that altitude influences physical signs. ${ }^{1314}$

However, no single sign was sufficiently sensitive and specific to be used as a single predictor. Only a combination of several independent highly specific markers was able to improve sensitivity without compromising specificity overmuch. We have restricted the final model of prediction of hypoxaemia to three elements that were consistent in both comparisons. Quality of cry and head nodding have the additional advantage that they can be taught easily to health professionals with a limited amount of training. Cyanosis is often difficult to detect, although when present it is highly specific for the presence of hypoxaemia. The combination of the three signs doubled the sensitivity of each individual sign, whereas it did not decrease the specificity substantially.

The weakness of the comparison of cases with control group 1 is the possibility of observer bias, as the allocation of the children to the control group was known to the observer. Therefore the findings in the comparison with control group 2 lend additional weight to the observations. However, control group 2 had a higher number of bronchiolitis cases and no child in the control groups had measles. This difference might have affected the results.

Comparing our results to other published suggestions, we found that the WHO guidelines $^{45}$ had a similar sensitivity but were slightly less specific. As only a minority of pneumonia cases will be hypoxaemic, this fall in specificity will result in overtreatment with oxygen, which does not matter where oxygen is available and cost considered negligible. However, in developing countries, indiscriminate oxygen treatment will make it unaffordable. In a setting where $15 \%$ of pneumonia cases are hypoxaemic, as in RVH (unpublished observations), a fall in specificity from $94 \%$ to $76 \%$ means that the number of children who receive oxygen but do not actually require it (false positives) quadruples. Two out of three children who receive oxygen in this scenario do not need it. Leaving the respiratory rate out of the WHO model resulted in a considerable increase in specificity and lost only $10 \%$ in sensitivity. The model based on cut off points in respiratory rate, as suggested from Kenya, ${ }^{1}$ did not perform as well as our model or the WHO guidelines. All three models showed a better sensitivity in the subgroup of children who were most profoundly hypoxaemic. A recent study from Papua New Guinea developed a model to increase the sensitivity of a combination of four clinical signs (cyanosis, grunting, reduced consciousness, respiratory rate above $90 / \mathrm{min}$ ) to $67 \%$, but the specificity of this model fell to $70 \%{ }^{15}$ 
The retrospective fitting of models to data maximises the predictive value of variables. To make best use of the variables we selected, they will have to be validated prospectively. Head nodding in particular has not been documented widely in studies. The attraction of the sign is the ease of recognition without undressing the child and the ease with which it can be taught to health professionals, provided it is validated in other studies.

Using only a limited number of physical signs, hypoxaemia will be missed in certain children, or oxygen will be wasted on children who do not really need it. Especially in a setting where oxygen has to be bought in cylinders, a pulse oximeter might be a cost effective purchase, as it allows children in need of oxygen to be identified, and the amount of oxygen given can be titrated to the actual need of the patient, thus avoiding wastage. In a more peripheral setting, where children will be screened by using physical signs as an aid for possible referral to bigger hospitals with a supply of oxygen, the teaching of signs predicting hypoxaemia will enable health professionals to refer the majority of patients in need of supplemental oxygen.

We thank the nursing staff and physicians in the children's ward of the RVH in Banjul and the ward of the MRC hospital in Fajara for the care of the study patients. The field assistants Fatou Bah, Isatou Kah, Ma'ansu Kinteh, and Mariama Mad were identifying patients and following them up closely. Thanks to Dr Brian Greenwood, Director of the MRC L aboratories in Fajara, and Dr Sandy Gove, Programme for the Control of Acute Respiratory Infections, WHO, Geneva, for their support. Acute Respiratory Infections, WHO, Geneva, for their support. The study was supported by the WHO Programme for the Control of Acute Respiratory Infections and the British MRC. MWW was supported part of the time by Deutsche Forschungs-
gemeinschaft grant We 1379/3-1.
1 Onyango FE, Steinhoff MC, Wafula EM, Wariua S, Musia J, Kitonyi J. Hypoxaemia in young Kenyan children with acute lower respiratory infection. BMf 1993;306:612-5.

2 Garenne M, Ronsmans C, Campbell H. The magnitude of mortality from acute respiratory infections in children under 5 years in developing countries. World Health Stat $Q$ 1992;45:180-91.

3 World Bank. World development report 1993. Investing in health. New York: Oxford University Press, 1993.

4 WHO programme for the control of acute respiratory infections. Oxygen therapy for acute respiratory infections in young children in developing countries. Geneva: WHO/ARI/93.28, 1993.

5 WHO programme for the control of acute respiratory infections. Acute respiratory infections in children: case management in small hospitals in developing countries. Geneva: WHO/ARI/ $90.5,1990$.

6 Stadie WC. The oxygen of the arterial and venous blood in pneumonia and its relation to cyanosis. $f$ Exp Med 1919;30:215-40.

7 Simpson H, Flenley DC. Arterial blood gas tensions and $\mathrm{pH}$ in acute lower respiratory tract infections in infancy and childhood. Lancet 1967;i:7-12.

8 Mulholland EK, Olinsky A, Shann FA. Clinical findings and severity of acute bronchiolitis. Lancet 1990;335:1259-61.

9 Margolis PA, Ferkol TW, Marsocci S, et al. Accuracy of clinical examination in detecting hypoxemia in infants with respiratory illness. F Pediatr 1994;124:552-60.

10 Morrison B. Anoxia in the acute respiratory infections of childhood. Lancet 1955;ii:737-40.

11 Shann F, Barker J, Poore P. Clinical signs that predict death in children with severe pneumonia. Pediatr Infect Dis $\mathcal{F}$ 1989;8:852-5.

12 Spooner V, Barker J, Tulloch S, et al. Clinical signs and risk factors associated with pneumonia in children admitted to Goroka hospital, Papua New Guinea. F Trop Pediatr 1989; 35:295-300.

13 Lozano JM, Steinhoff M, Ruiz JG, Mesa ML, Martinez N, Dussan B. Clinical predictors of acute radiological pneumonia and hypoxaemia at high altitude. Arch Dis Child 1994;71:323-7.

14 Reuland DS, Steinhoff MC, Gilman RH, et al. Prevalence and prediction of hypoxemia in children with respiratory infections in the Peruvian Andes. F Pediatr 1991;119:9006.

15 Dyke T, Lewis D, Heegaard W, Manary M, Flew S, Rudeen $\mathrm{K}$. Predicting hypoxia in children with acute lower respiratory infection: a study in the highlands of Papua New Guinea. F Trop Pediatr 1995;41:196-201. 